\title{
MOOCS and Higher Education Globalisation: Social Work and Social Education Students' Perspectives
}

\author{
Manuel León-Urrutia \\ m.Leon-Urrutia@soton.ac.uk \\ Orcid: 0000-0002-6358-7617 \\ Universidad de Southampton \\ Esteban Vázouez Cano \\ evazquez@edu.uned.es \\ Orcid: 0000-0002-6694-7948 \\ Universidad Nacional de \\ Educación a Distancia.
}

\author{
Eva Ordóñez Olmedo \\ eva.ordonez@ucavila.es \\ Orcid: 0000-0002-6220-0302 \\ Universidad Católica de Ávila \\ Eloy López Meneses \\ elopmen@upo.es \\ Orcid: 0000-0003-0741-5367 \\ University of Pablo de Olavide
}

\begin{abstract}
M00Cs can support educational innovation in a wide range of contexts, from formal to informal and from expected to unexpected. This kind of open online courses are often used within campus modules as core elements of their curriculum. This is the case of this experimental study, where we analyse an experiment of HE educational innovation about the perceptions of students around strengths and weaknesses of MOOCs in socio-educational settings. 54 students were surveyed with multiple choice questions around this topic. The results show that HE students of education degrees tend to see the potential of MOOCs to aid the transformation of the classrooms often currently reserved to social elites. They also see that MOOCs can transcend to new learning arenas more ubiquitous, connected, informal and horizontal, which can facilitate the digital inclusion of disenfranchised groups, as well as potentiate the blooming of interactive communities of collective intelligence. However, these students were also aware of important shortcomings such as the lack of monitoring, and MOOC's often unattainable demand of high learner autonomy.
\end{abstract}

Keywords: M00Cs, education innovation, M00Cs within campus, M00Cs for inclusion 


\subsection{M00Cs and learning models in Higher education and Society}

Conner (2013) suggests that learning in the Knowledge Society occurs in a diversity of contexts, ranging from formal to informal and from expected to unexpected (figure 1).

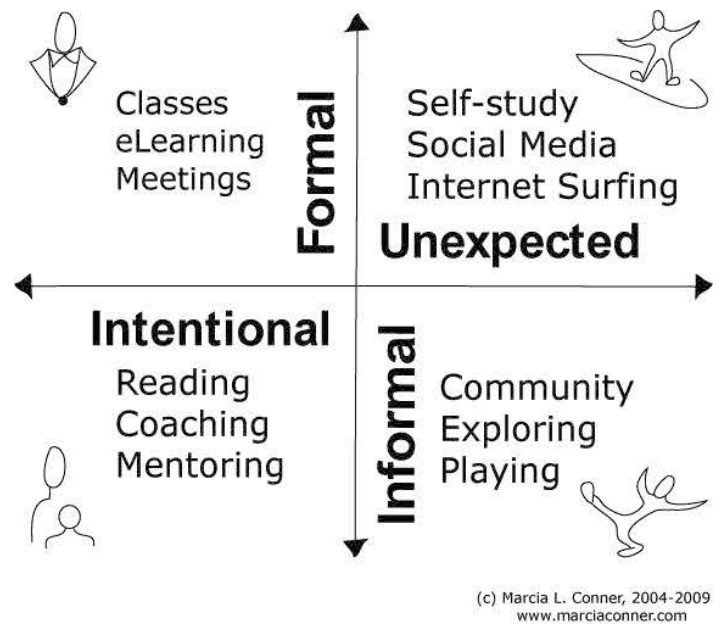

Figure 1. Learning contexts (Conner, 2013).

In this sense, MOOCs are interesting educational approaches to develop in this polychromatic plurality of educational contexts.

MOOC acronym stands for Massive Open Online Courses (Rheingold, 2013). In scientific literature, MOOCs are often portrayed as virtual environments of social connectivity around a particular area of study with an open pedagogical approach (McAuley et al., 2010; Vázquez-Cano, López-Meneses \& Barroso, 2015; Aguaded, Vázquez-Cano \& López Meneses, 2016). These are in turn offered by many of the top Higher Education Institutions (HEIs) worldwide, and have the potential to alter the global Higher Education ecosystems (López-Meneses, 2017). Castaño \& Cabero outline the following characteristics of MOOCs:

- They are educational resources with certain resemblance to a classroom. 
- They are events with start and finish dates.

- They have assessment mechanisms.

- They are online.

- They are free for learners to use.

- They are open, without admission prerequisites.

- They allow interactive participation at scale of large learning communities.

The MOOC universe is object of pedagogical and educational reflection among many academics in the field (Zapata, 2013; Ramírez-Fernández, Salmerón y López-Meneses, 2015) as well as for HEIs in the globalised world (Haggard, 2013). That entails an innovative model of massive education that exploits the potential of communication and information technologies in a paradigmatic fashion at societal level (Pérez-Parra \& Gómez-Galán, 2015). In the same way, massive and open education poses a challenge for HEIs and the HE teaching community, who is pushed to redefine the current methodological paradigm in order to charter new curricular approaches which are more open, interactive, collaborative and ubiquitous, in symbiosis with a more dynamic and holistic assessment, embedded in more flexible and diversified programmes, more adapted to the job market to promote and provide students with the implementation of their own skills and competencies development paths for their academic and professional development (López-Meneses, 2017).

Many attempts have been made at classifying the different types of MOOCs. Perhaps one of the most commented taxonomies is that of Clark's (2013), who identifies seven types:

- TransferMOOCs (consisting of taking existing in-campus courses and transferring them to MOOC platforms).

- MadeMOOCs (purpose-made MOOCs with emphasis on the quality of the multimedia materials and MOOC-specific tasks and interactions for students).

- SynchMOOCs (courses have start and end dates, as well as specific assessment events).

- AsynchMOOCs (self-paced, with no dates or deadlines).

- AdaptiveMOOCs (using adaptive algorhitms to personalise learning, based on learning analytics insights).

- GroupMOOCs (designed for specific groups) 
- ConnectivistMOOCS (following Siemens' and Downes' connectivist principles).

- MiniMOOCSs (with small numbers and short duration).

However, the most generalised classification is that of $\mathrm{xMOOCs}$ and cMOOCs, where the former is a centralised approach with behaviourist pedagogical underpinnings, and the latter is a distributed approach with social constructivist and connectivist pedagogies (Downes, 2012; Karsenti, 2013; Vázquez-Cano, López-Meneses, \& Sarasola, 2013).

As Aguaded \& Medina suggest (2015) the MOOC movement currently emanates from a process of innovation in the context of open education, oriented by the principles of massive and free distribution of contents, and technologically facilitated by online, interactive and collaborative applications. Gértrudix, Rajas, \& Álvarez (2017) note that his movement has significant academic and journalistic attention, as evidenced by the bibliometric analyses of academic ( López-Meneses, Vázquez-Cano, \& Román, 2015; Aguaded, Vázquez-Cano, \& López-Meneses, 2016; León-Urrutia, Vázquez-Cano, \& López-Meneses, 2017) and non-academic literature (White, León, \& White, 2015; Kovanovich et al., 2015). This attention is also reflected in the institutional policies that stimulate MOOC production (Hollands \& Tirthali, 2014), and the analysis of their pedagogical quality (Roig-Vila, Mengual-Andrés, \& Suárez-Guerrero, 2014; Aguaded \& Medina-Salguero, 2015), among other areas. MOOCs can be therefore considered as a new learning path for universal education.

\subsection{The setting}

In this study, we analyse an experiment of HE educational innovation about the perceptions of 54 students of an Education degree module named "Information and Communication Technologies" in the double degree of Social Work and Social Education, from the cohort of February 2016-17, in the University Pablo Olavide of Seville. One of the core contents of these modules are MOOCs and their social and educational impact (see module in <http:// bit.ly/2xwjh4x>). 
This experiment encourages first-year Social education students to reflect upon the advantages and disadvantages of MOOC in socio-educational settings. For this, every student would produce a personal edublog for the module, keeping record the activities carried out in it. One of the tabs would be a record of the MOOCs where they would contribute with their reflections. In figure 2, two exemplars are displayed.

\section{Edublog 1}

URL: http://laurayebenestic.blogspot.com.es /p/mooc.html

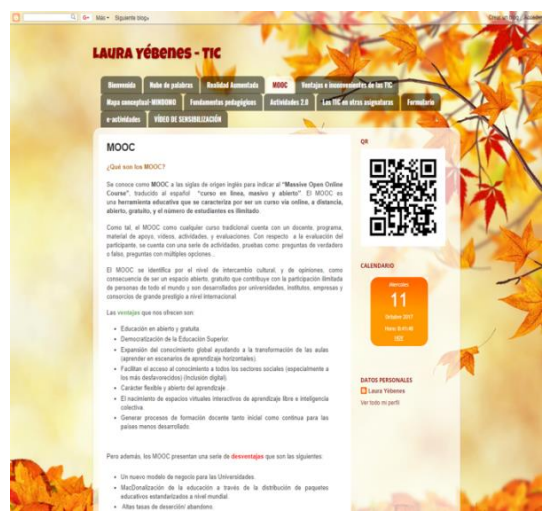

Edublog 2

URL: http://educametetic.blogspot.com.es |p/mooc.html

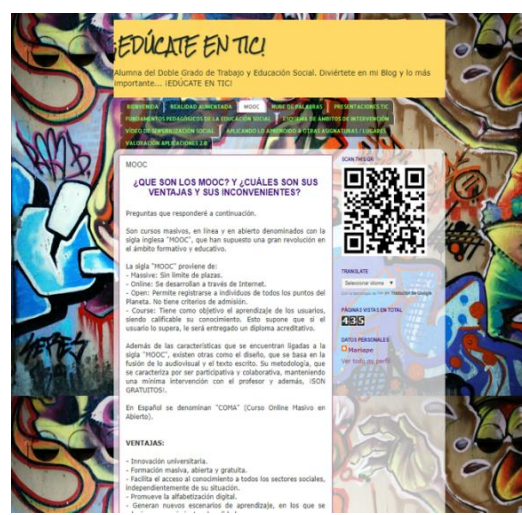

Figure 2. Personal edublog exemplars

\subsection{Aims}

The structure of this study was devised in attention to its main aims, which are the following:

- Analysing how students perceived the advantages of MOOCs in socio-educational settings where students of this particular module operate.

- Determine the main weaknesses of MOOCs as seen by the students of the module.

- Enhance our understanding of edublogs as educational resources, and find how to best use them to support the professional development of the social educator. 


\subsection{Methodology}

This research Project used qualitative and descriptive methodological approach. The sample was formed by 54 students of the double degree of Social Work and Social Education, in the Faculty of Social Science of the University Pablo Olavide, cohort 2016/17.

To analyse the different students' outputs (comments made in the individual edublogs) throughout the module, a reference framework was taken from the guidelines established by Bogdan \& Biklen (1992); Miles \& Huberman (1994), and Monje (2011).

The first stage of the data analysis process consisted of data reduction by categorising and coding the information obtained. The categorisation involved simplifying and selecting the information in order to make it more manageable. For this, the following steps were followed:

- Units were separated to identify relevant instances about reflections on advantages and drawbacks of MOOCs in socio-educational settings.

- These units were grouped in themes.

- The instances were synthesised and classified into those different themes.

During the coding stage, each textual instance was identified and inserted into its corresponding category through a mixed inductive-deductive procedure, to then perform a statistical analysis of the counts obtained. Finally, the analysis process was completed with a second stage in which the different instances were interpreted and categorised, in order to facilitate the inferences and interpretations of the results, as described below.

\subsection{Results}

This section starts with the analysis of the study participants' reported perceptions with regard of the strengths of MOOCs in socio-educational settings. More specifically, Table 1 displays the frequencies of participants' responses around this topic. From the table it can be inferred that most students saw gratuity as one of the main advantages of this approach for knowledge expansion, 
followed by 46 students who thought that its greatest advantage is the flexibility that MOOCs provide, adapting to the learners' availability and ability to devote time to those courses. It is also worth highlighting the 33 responses stating MOOC's ability to create learning communities and networks, from pools of massive numbers of participants, facilitated by discussion forums (32 responses specific to fora). Moreover, 31 students highlighted the inclusive nature of MOOCs, enabling access to disenfranchised groups.

Table 1. Participants' responses on $\mathrm{MOOC}$ strengths

\begin{tabular}{lc}
\hline MOOC advantages & FREQUENCIES \\
\hline Gratuity & 47 \\
\hline Higher education content & 24 \\
\hline Flexibility & 18 \\
\hline Width of choice & 31 \\
\hline Education for the disenfranchised & 9 \\
\hline Employability & 10 \\
\hline Support to traditinal education & 32 \\
\hline Discussion forums & 4 \\
\hline Multimedia materials & 19 \\
\hline Introductory topics and life-long learning & 12 \\
\hline Online education & 33 \\
\hline Collaborative social networks & 14 \\
\hline Certification & 9 \\
\hline Unlimited enrolments & \\
\hline
\end{tabular}

24 responses agreed that MOOCs offer Higher Education contents, signed off by prestigious universities. 19 of the responses indicated that MOOCs can introduce learners to scientific topics and disciplines, as well as providing live-long learning experiences, with a wide variety of offerings (18 responses). 


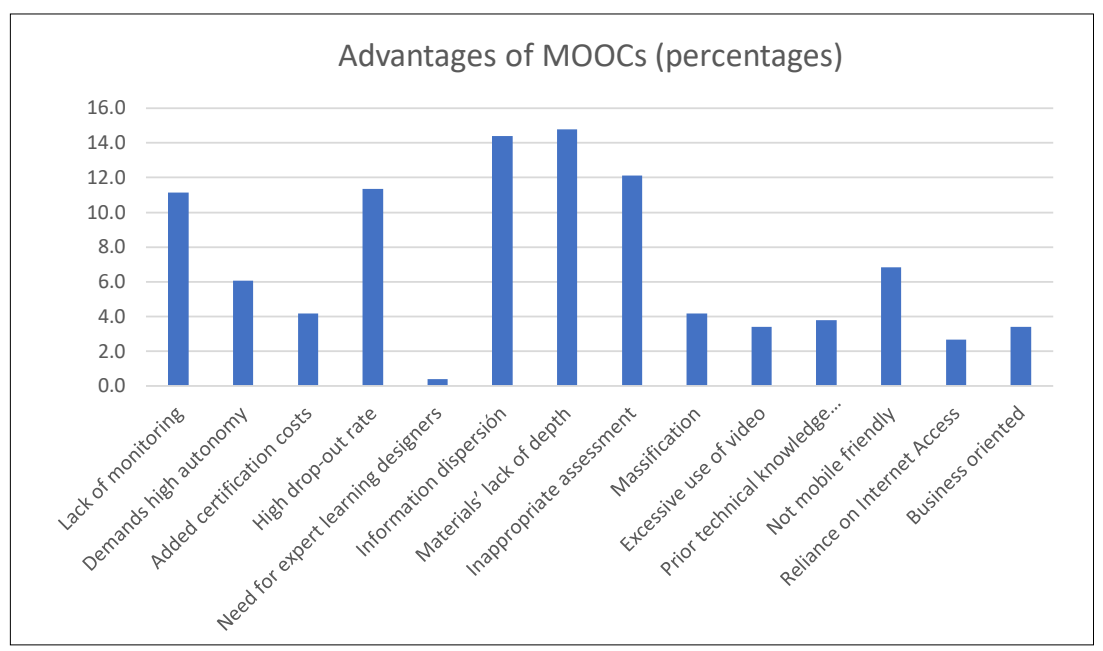

Chart 1. Percentages of responses from participants about advangages of MOOCs

In light of the results obtained referring to the advantages of MOOCs, it can be inferred that these courses have a significant potential to offer affordable and accessible education to everyone regardless of their background, as others have already suggested (Christensen et al., 2013; Daniel, 2012). The results show that this is also true in our social and educational settings, where these courses can support the digital inclusion of disenfranchised groups (Vázquez-Cano, López-Meneses, \& Sarasola, 2013). Finally, in consonance with Moser-Mercer (2014), learning in "fragile" contexts is fundamental for an equal societal development, as well as the internalisation of HEIs (Teixeira et al. 2016).

With regard of the main challenges and dificulties of the MOOC movement in socio-educational settings, Chart 2 higlights a $15 \%$ of participants noting a lack of depth in the contents and materials offered in MOOCs. To this respect, as pointed out by Daniel, Vázquez-Cano, \& Gisbert (2015), too many MOOCs are designed as a collection of videos with a discussion forum, which involves a traditional distance learning model that does not promote personalised learning. This in turn leads to a unidirectional teacher-centred content-based communicative design, with serious issues in attending individual differences, in a tendency to standardise learning (Valverde, 2014). In this sense, other authors (Lane \& Kinser, 2013; Aguaded, Vázquez-Cano, \& Sevillano, 2013) 
use the term McDonalisation of education to refer to the distribution of standardised educational packs at global scale. Also, over $10 \%$ of the participants expressed that these courses lack appropriate and quality-ensuring assessment systems.

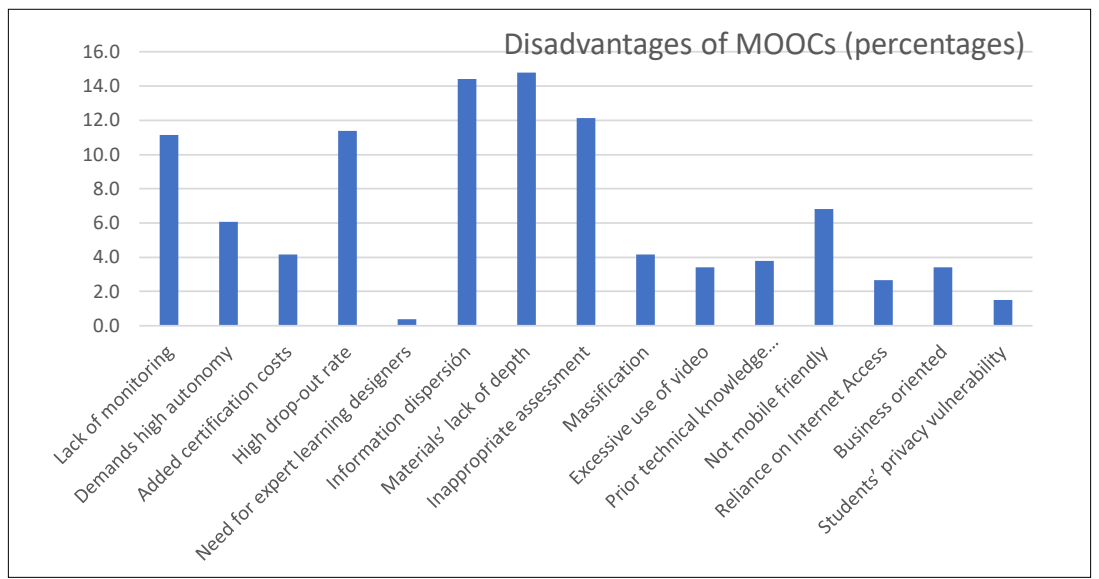

Chart 2. Participants'opinions about MOOC weaknesses, in percentages

There was also a $14.39 \%$ who stated that most MOOCs, due to their massiveness, come with an information deluge that could lead to dispersion and disorientation. In this sense, Calderón, Ezeiza, \& Jimeno (2013) pointed out that some learners who feel disoriented and overwhelmed have low probabilities of interaction with tutor or expert co-learners, little meaningful socialisation in the MOOC, and little depth in their interactions.

$12.12 \%$ of the participants also identified the predominance of multiple choice questions in the MOOC assessment methods as one of their main drawbacks. Another widely criticised aspect of MOOCs $(11.36 \%)$ was the high attrition rates, in line with Fidalgo, Sein-Echaluce, \& García Peñalvo (2013). Also, almost 11\% expressed that MOOC lacked an appropriate follow up of the learning process.

Other reported weaknesses worth mentioning were MOOC's non-mobile friendliness (18), a high reliance on students' autonomy (16), and additional costs for certificate obtention (11). See table 2 for all the results about MOOCs' weaknesses. 
Table 2. Frequencies of participants' responses in relation to M00Cs' weaknesses

\begin{tabular}{|c|c|}
\hline MOOC weaknesses & FREQUENCIES \\
\hline Lack of monitoring & 29 \\
\hline Demands high student autonomy & 16 \\
\hline Added certification costs & 11 \\
\hline High drop-out rate & 30 \\
\hline Need for expert learning designers & 1 \\
\hline Information dispersión & 38 \\
\hline Materials' lack of depth & 39 \\
\hline Inappropriate assessment & 32 \\
\hline Massification & 11 \\
\hline Excessive use of video & 9 \\
\hline Prior technical knowledge requirements & 10 \\
\hline Not mobile friendly & 18 \\
\hline Reliance on Internet Access & 7 \\
\hline Business oriented & 9 \\
\hline Students' privacy vulnerability & 4 \\
\hline
\end{tabular}

Another 10 participants indicated that MOOC often required too much previous technical knowledge to get started with the course. Also, 9 of the participants expressed that there was an abuse of video materials in detriment of other formats, an unbalanced that affected the quality of the courses (Zapata, 2013; Vázquez-Cano, López, \& Sarasola, 2013).

Finally, seven participants indicated the indispensability of a working Internet connection as a significant weakness. One of the students also expressed that quality MOOCs could not be delivered without specialist learning designers. In this sense, León-Urrutia, Vázquez-Cano, \& López-Meneses (2017), suggested that MOOC designers must provide a more comprehensive and adaptive design to cater for different socio-educational realities, in order to address the diverse training and educational demands. 


\subsection{Discussion and conclusion}

One of the most salient features of the current Information Society is the relevance that Information and Communication Technologies have been gaining recently, becoming elements for exclusion and discrimination in a wide range of social contexts (Cabero-Almenara, \& Ruiz-Palmero, 2018). Martín-Padilla (2017) indicates that this is especially true for MOOCs.

Moreover, universities are socio-technical pillars for the expansion and dissemination of global knowledge, as well as for the empowerment of citizenship, educational innovation, knowledge transfer. Universities are also catalysts for professional development, social cohesion, and an integrating agent for the economic and technological fabric of the knowledge society and human development (López-Meneses, 2017). Under this socio-technical and educational perspective, MOOCs can aid the transformation of the classrooms often currently reserved to social elites. MOOCs can transcend to new learning arenas more ubiquitous, connected, informal and horizontal, which can facilitate the digital inclusion of disenfranchised groups, as well as potentiate the blooming of interactive communities of collective intelligence. However, we must be aware that, after of a first phase of effervescence in $\mathrm{HE}$, a set of shortcomings have become evident, as participants in this study have identified, and other authors have corroborated. These are, among others, the high attrition rate, the scarce interactivity of MOOC participants, the weaknesses in the official recognition through creditation, and the tendency to monetisation over quality (Aguaded, Vázquez-Cano, \& Sevillano, 2013; Daniel, Vázquez-Cano, \& Gisbert, 2015; León-Urrutia, Vázquez-Cano, \& López-Meneses, 2017). An awareness of these shortcomings, as well as these advantages, can support a transformation towards more horizontal, connected, informal, and inclusive educational offerings, creating virtual habitats for sustainable educational development for the Homo Conexus/digitalis in the path of globalised knowledge (Vázquez-Cano, López-Meneses, \& Barroso, 2015). 


\section{Acknowledgements}

This study emerges from the directive of the pedagogical innocation Project called "Formación didáctica en Cloud Computing: Competencias digitales, estrategias didácticas y e-actividades con tecnología Web 2.0 en el EEES", in the framework of the Action 2 of Projects for Pedagogical Innovation and Teacher Development, funded by the Vice-Chancellor office of the University Pablo Olavide of Seville, under the umbrela of the EduInnovagogía (HUM971) research group.

\section{References}

Aguaded, J. I. \& Medina-Salguero, R. (2015). Criterios de calidad para la valoración y gestión de MOOC, RIED. Revista Iberoamericana de Educación a Distancia, 18 (2), 119-143. Available at <http://bit.ly/2ql8i71>. Aguaded, J. I., Vázquez-Cano, E., \& Sevillano, M. L. (2013). MOOCs, iturbocapitalismo de redes o altruismo educativo? In SCOPEO INFORME Num. 2: MOOC: Estado de la situación actual, posibilidades, retos y futuro, 74-90. Salamanca: Universidad de Salamanca. Servicio de Innovación y Producción Digital. Available at <http://scopeo.usal.es/ wp-content/uploads/2013/06/scopeoi002.pdf>.

Aguaded, J. I., Vázquez-Cano, E., \& López-Meneses, E. (2016). El impacto bibliométrico del movimiento MOOC en la comunidad científica española, Educación XX1, 19 (2), 77-104. doi: <https://doi.org/10.5944/ educxx1.19.2>.

Bogdan, R. \& Biklen, S.K. (1992). Investigación cualitativa de la educación. Needham Heights, MA: Allyn and Bacon.

Cabero, J. \& Ruiz-Palmero, J. (2018). Las tecnologías de la información y la comunicación para la inclusión: reformulando la brecha digital, International Journal of Educational Research and Innovation (IJERI), 9, 16-30.

Calderón, J. J., Ezeiza, A., \& Jimeno, M. (2013). La falsa disrupción de los MOOC: la invasión de un modelo obsoleto. VI Congreso Internacional de Educación Abierta y Tecnología Ikasnabar'13, Zalla.

Castaño, C. \& Cabero, J. (2013). Enseñar y aprender en entornos m-learning. Madrid: Síntesis.

Christensen, G., Steinmetz, B., Alcorn, B., Bennett, A., Woods, D., \& Emanuel, E. J. (2013). The MOOC phenomenon: Who takes Massive Open Online Courses and why? Available at <http://bit.ly/2pqRDlv>. 
Clark, D. (2013). MOOCs: taxonomy of 8 types of MOOC.onald Clark Plan B. Available at <http://arkplanb.blogspot.com.es/2013/04/moocs-taxonomy-of-8-types-of-mooc.html>.

Conner, M. L. (2013). Informal Learning. Available at <http://marciaconner.com/resources/informallearning/>.

Daniel J. (2012). Making sense of MOOCs: Musings in a Maze of Myth, Paradox and Possibility, Journal of Interactive Media in Education, 3. Available at <http://doi.org/10.5334/2012-18>.

Daniel, J.; Vázquez-Cano, E., \& Gisbert, M. (2015). El futuro de los MOOC: ¿aprendizaje adaptativo o modelo de negocio?, RUSC. Universities and Knowlwdge Society Journal, 12 (1), 64-74.

Downes, S. (2012). Connectivism and Connective Knowledge Essays on meaning and learning Networks. National Research Council Canada. Available at <http://bit.ly/2oTNdk3>.

Fidalgo, Á., Sein-Echaluce, M. L., \& García-Peñalvo, F. J. (2013). MOOC cooperativo. Una integración entre cMOOC y xMOOC. In Fidalgo, A., Sein-Echaluce, M. L., \& Lacleta (eds.) Actas del II Congreso Internacional sobre Aprendizaje, Innovación y Competitividad, CINAIC 2013 (6-8 de noviembre de 2013), pp. 48-486. Madrid, España: Fundación General de la Universidad Politécnica de Madrid.

Gértrudix, M., Rajas, M., \& Álvarez, S. (2017). Metodología de producción para el desarrollo de contenidos audiovisuales y multimedia para MOOC, RIED. Revista Iberoamericana de Educación a Distancia, 20 (1). Available at <http://revistas.uned.es/index.php/ried/article/ view/16691/14643>.

Haggard, S. (2013). The Maturing of the MOOC (Reserch No. 130). London: Department for Business Innovation y Skills-UK Government. Available at <http://bufvc.ac.uk/copyright-guidance/mlr/index.php/ site/323>.

Hollands, F. \& Tirthali, D. (2014). MOOCs: Expectations and Reality. Full Report. New York: Columbia University. Available at <http://cbcse. org/wordpress/wp-content/uploads/2014/05/MOOCs_Expectations_ and_Reality.pdf>.

Karsenti, T. (2013). MOOC: Révolution ou simple effet de mode?/The MOOC: Revolution or just a fad?, International Journal of Technologies in Higher Education, 10 (2), 6-37. doi: <https://doi.org/10.7202/1035519ar>.

Kovanović, V., Joksimović, S., Gašević, D., Siemens, G., \& Hatala, M. (2015). What public media reveals about MOOCs: A systematic analysis of news reports, British Journal of Educational Technology, 46 (3), 510-527. 
Lane, J. \& Kinser, K. (2013). MOOC's and the McDonalization of Global Higher Education. The Cronicle of Higer Education. Available at <http:// chronicle.com/blogs/worldwise/moocs-mass-educationand-the-mcdonaldization-of-higher-education/30536>.

León-Urrutia, Vázquez-Cano \& López-Meneses (2017). Analítica de aprendizaje en MOOC mediante métricas dinámicas en tiempo real, @tic. Revista d'Innovació Educativa, 18, 38-47. Available at <https://ojs. uv.es/index.php/attic/article/viewFile/10022/9798>.

López-Meneses, E., Vázquez-Cano, E., \& Román, P. (2015). Análisis e implicaciones del impacto del movimiento MOOC en la comunidad científica: JCR y Scopus (2010-13), Comunicar, 44, 73-80. doi: <http:// dx.doi.org/10.3916/C44-2015-08>.

López-Meneses, E. (2017). El fenómeno MOOC y el futuro de la Universidad, Fronteras de la Ciencia, 1, 90-97.

Martín-Padilla, A. H. (2017). Diseño e implementación de un observatorio de investigación sobre MOOC para la expansión del conocimiento global. (Tesis doctoral inédita). Universidad de Almería, Facultad de Educación, España.

McAuley, A.; Stewart, B.; Siemens, G., \& Cormier, D. (2010). Massive Open Online Courses. Digital ways of knowing and learning. The MOOC Model for Digital Practice. University of Prince Edward Island. Available at $<$ http://davecormier.com/edblog/wp-content/uploads/MOOC_ Final.pdf>.

Miles, M. B. \& Huberman, A. (1994). Qualitative data analysis: an expanded sourcebook. Newbury Park, CA: Sage.

Monje, C. A. (2011). Metodología de la investigación cuantitativa y cualitativa. Guía didáctica. Nieva: Universidad Surcolombiana. Facultad de Ciencias Sociales y Humanas. Programa de Comunicación Social y Periodismo.

Moser-Mercer, B. (2014). MOOCs in fragile contexts. In Cress, U. \& Delgado Kloos, C. (eds.), Proceedings of the European MOOC Stakeholder Summit 2014. Lausan: PAU Education, pp. 114-221. Available at <http://bit.ly/2oQDFW0>.

Pérez-Parras, J. \& Gómez-Galán, J. (2015). International Journal of Educational Excellence, 1 (2), 81-99.

Ramírez- Fernández, M. B., Salmerón, J. L., \& López-Meneses, E. (2015). Comparativa entre instrumentos de evaluación de calidad de cursos MOOC: ADECUR vs Normas UNE 66181:2012, RUSC Universities and Knowledge Society Journal, 12 (1), 131-144. Available at <http://dx.doi. org/10.7238/rusc.v12i1.2258>. 
Rheingold, H. (2013). MOOCs, Hype, and the Precarious State of Higher Ed: Futurist Bryan Alexander. Available at <http://dmlcentral. net/blog/howard-rheingold/moocs-hype-and-precarious-statehigher-ed-futurist-bryan-alexander>.

Roig-Vila, R., Mengual-Andrés, S. \& Suárez-Guerrero, C. (2014). Evaluación de la calidad pedagógica de los MOOC. Revista Profesorado. Currículum y Formación del Profesorado, 18 (1), 27-41. Available at <http:// bit.ly/2oB6f2q >.

Teixeira, A., Mota, J., García-Cabot, A., García López, E., \& De-Marcos, L. (2016). Un nuevo enfoque basado en competencias para la personalización de MOOCs en un entorno móvil colaborativo en red, RIED. Revista Iberoamericana de Educación a Distancia, 19 (1), 143-160.

Valverde, J. (2014). MOOCs: Una visión crítica desde las Ciencias de la Educación, Revista Profesorado. Currículum y Formación del Profesorado, 18 (1), 93-111.

Vázquez-Cano, E., López-Meneses, E., \& Sarasola, J. L. (2013). MOOCs and the Expansion of Open Knowledge. Barcelona: Octaedro.

Vázquez-Cano, E., López Meneses, E., \& Barroso, J. (2015). El futuro de los MOOC: Retos de la formación on-line, masiva y abierta. Madrid: Síntesis.

White, S., Leon, M., \& White, S. (2015, May). MOOCs Inside Universities. In Proceedings of the 7th International Conference on Computer Supported Education, pp. 109-115.

Zapata, M. (2013). MOOCs, una visión crítica y una alternativa complementaria: la individualización del aprendizaje y de la ayuda pedagógica, Campus Virtuales, II (1), 20-38. 
